\title{
Regulation of leptin synthesis and secretion before birth: implications for the early programming of adult obesity
}

\author{
I C McMillen, L J Edwards, J Duffield and B S Muhlhausler \\ Research Centre for the Early Origins of Adult Health, Discipline of Physiology, School of Molecular \\ and Biomedical Sciences, University of Adelaide, South Australia 5000, Australia
}

Correspondence should be addressed to I C McMillen; Email: caroline.mcmillen@unisa.edu.au

I C McMillen is now at Sansom Research Institute, University of South Australia, Adelaide, South Australia 5005, Australia

\begin{abstract}
A series of epidemiological, clinical and experimental studies have shown that there are associations between the fetal and neonatal nutritional environment and the amount and distribution of adipose tissue in adult life. This review considers the evidence for these relationships and discusses the potential impact of the prenatal nutritional experience on the development of the endocrine and neuroendocrine systems that regulate energy balance, with a particular emphasis on the role of the adipocyte-derived hormone, leptin. In the rodent, leptin derived from the mother may exert an important influence on the development of the appetite regulatory neural network and on the subsequent regulation of leptin synthesis and the risk for obesity in the offspring. In species such as the human and sheep, there is also recent evidence that the synthesis and secretion of adipocyte-derived hormones, such as leptin, are regulated in fetal life. Furthermore, the hypothalamic neuropeptides that regulate energy intake and expenditure in adult life are also present within the fetal brain and may be regulated by the prevailing level of maternal and hence fetal nutrient and hormonal signals, including leptin. This work is important in determining those initiating mechanisms within the 'fat-brain' axis in early life that precede the development of adult obesity. Reproduction (2006) $131415-427$
\end{abstract}

\section{Introduction}

Currently more than half of all adults in the United States and the United Kingdom are either overweight (i.e. have a body mass index (BMI) over $25 \mathrm{~kg} / \mathrm{m}^{2}$ ) or obese (i.e. have a BMI over $30 \mathrm{~kg} / \mathrm{m}^{2}$ ) (James 1996, Campfield et al. 1998, Flegal et al. 2002, Ogden et al. 2002). Adult obesity is associated with the co-morbidities of type 2 diabetes, high blood pressure and ischaemic heart disease, and consequently incurs significant health-care costs (James 1996). Abdominal or visceral obesity in particular is associated with the metabolic or 'insulin-resistance' syndrome, i.e. the presence of insulin resistance (with or without glucose intolerance), raised blood pressure, atherogenic dyslipidaemia, and prothrombotic and proinflammatory states (Reaven 1988). The difficulty of effective intervention in obesity is well established and this difficulty relates in part to the complexities of an energy balance regulating system that has evolved features reflecting the requirements, present for most of human history, to protect and maintain energy stores in order to survive long periods of famine, rather than feasting.

In this context, it is of interest that epidemiological, clinical and experimental studies have shown that there are associations between the early nutritional environment, patterns of postnatal growth and the amount and distribution of adipose tissue in adult life (Fall et al. 1995b, Sorensen et al. 1997, Loos et al. 2001b, Yajnik 2003). This review considers the evidence for these relationships and discusses the potential impact of the prenatal nutritional experience on the development of the endocrine and neuroendocrine systems that regulate energy balance, with a particular emphasis on the role of the adipocyte-derived hormone, leptin.

\section{Birth weight and adult obesity}

The relationship between birth weight and fatness, measured in childhood or adulthood, is generally positive, although a number of studies have reported that there is a J-shaped or U-shaped relationship between birth weight and adult fat mass, with a higher prevalence of obesity occurring at both low and high birth weights (Maffeis et al. 1994, Curhan et al. 1996a, 1996b, Parsons et al. 2001). A study in a large British cohort found a weak but positive relationship between birth weight and BMI at 33 years of age and determined that this relationship was largely accounted for by maternal weight, i.e. heavier mothers had heavier babies and these babies went on to have a 
high BMI in adult life (Parsons et al. 2001). It has been suggested that the influence of maternal weight on the relationship between birth weight and subsequent BMI may operate through an impact of a high maternal and hence fetal nutrient supply. In diabetic or glucose-intolerant mothers, maternal and fetal blood glucose levels are higher and this results in offspring who are heavier at birth and who are at risk of developing obesity and glucose intolerance in later life (Silverman et al. 1991, Dorner \& Plagemann 1994). Thus an increase in fetal nutrient supply, as a consequence of an increase in maternal energy intake or resulting from maternal glucose intolerance, may program childhood and later obesity.

While people who were small babies tend to have a lower BMI in adult life than people who were larger at birth, these individuals have a more central distribution of obesity, a significantly reduced muscle mass and a high body fat content in adolescent and adult life (Law et al. 1992, Fall et al. 1995a, Malina et al. 1996, Okosun et al. 2000, Loos et al. 2001a, 2002, Singhal et al. 2003). Exposure to a reduced nutrient supply in the first trimester, as occurred in the Dutch Winter Famine in 1944-1945, also resulted in increased fat mass in later life (Ravelli et al. 1976). Parsons and colleagues (2001) have shown that those low birth weight babies who were most vulnerable to developing obesity were men who had been light and thin at birth and had experienced a period of rapid childhood growth. A range of studies have also shown that people who were thin at birth but who developed obesity in childhood or adulthood have the highest risk of insulin resistance and cardiovascular disease (Bavdekar et al. 1999, Eriksson et al. 2002).

While there are clear associations between birth weight, early childhood growth and the pattern of adult obesity, the mechanisms underlying these associations are unknown. The two primary targets for the 'programming' of adult obesity are: (a) the developing fat cell and the synthesis and secretion of adipokines, such as leptin; and (b) the neuroendocrine network that regulates appetite and energy balance in adult life.

\section{Early nutrition and programming of adipose tissue and leptin synthesis and secretion in the human}

In the human infant, there is a positive relationship between cord blood concentrations of leptin at delivery and birth weight or neonatal adiposity. In pregnancies complicated by maternal diabetes, the fetus is hyperglycaemic, hyperinsulinaemic and hyperleptinaemic (Koistinen et al. 1997, Matsuda et al. 1997, Jaquet et al. 1998, Shekhawat et al. 1998, Cetin et al. 2000, Tapanainen et al. 2001). Newborn infants who are small for their gestational age (SGA) also show a marked reduction in body fat mass at birth, which mainly reflects a decreased accumulation of lipid in the adipocytes (Levy-Marchal et al. 2004). Children born SGA who grow rapidly in infancy have an increased body fat mass but they have a more central distribution of adipose tissue when compared with children born at normal birth weight (Levy-Marchal et al. 2004). While plasma leptin concentrations are low in growth-restricted infants at birth, they increase to become higher in these infants at 1 year of age when compared with their normal birth weight counterparts (Jaquet et al. 1999). People with a low birth weight also go on to have higher leptin concentrations in adult life when compared with individuals with the same adult BMI but who had a higher birth weight (Phillips et al. 1999). There is also evidence that nutrition in the early postnatal period may be an important determinant of the future leptin synthetic capacity of adipose cells. One study reported that the ratio of leptin to fat mass in adolescents was significantly greater in those who had received a nutrient-enriched formula than in those who received a standard formula or banked breast milk after pre-term delivery (Singhal et al. 2002). Human milk intake was also associated with lower leptin concentrations relative to fat mass in adolescence (Singhal et al. 2002). It has therefore been suggested that programming of leptin synthesis or secretion in adipocytes by early nutritional exposure may be one mechanism that links early nutrition with later obesity (Singhal et al. 2002). Thus a programmed alteration in the synthesis, secretion or actions of leptin may play a role in the early origins of later obesity following exposure to either relative over- or undernutrition in early life (Figs 1 and 2).

\section{The role of leptin in adult obesity}

The adipocyte-derived hormone, leptin, a polypeptide $(\sim 16 \mathrm{kDa})$, is synthesised and secreted by adipose tissue and acts as a circulating signal of fat mass through binding to specific receptors at a number of central and peripheral sites to decrease food intake and increase energy utilisation (Friedman \& Halaas 1998, Ahima \& Flier 2000, Schwartz 2001). In the adult, appetite and energy balance homeostasis are primarily regulated by a neuronal network within the hypothalamus which receives nutrient, hormonal and neural signals from a range of sources including adipocytes, the pancreas, the gastrointestinal tract and other brain regions. There are a range of appetite regulatory neuropeptides, which either stimulate appetite (e.g. neuropeptide $\mathrm{Y}(\mathrm{NPY})$ and agouti-related protein (AgRP)) or inhibit it (e.g. pro-opiomelanocortin (POMC) and cocaine- and amphetamine-regulated transcript (CART)) (Schwartz 2001). The blood-brain barrier is effectively reduced within the area of the arcuate nucleus and NPY neurones are therefore able to sense and respond to a range of peripheral metabolic signals including leptin, insulin and glucose. The leptin receptor (OB-Rb) is highly expressed on cell bodies in the arcuate (ARC) nucleus of the hypothalamus and increases in circulating leptin concentrations during periods of increased food intake result in a decrease in hypothalamic NPY mRNA and a 


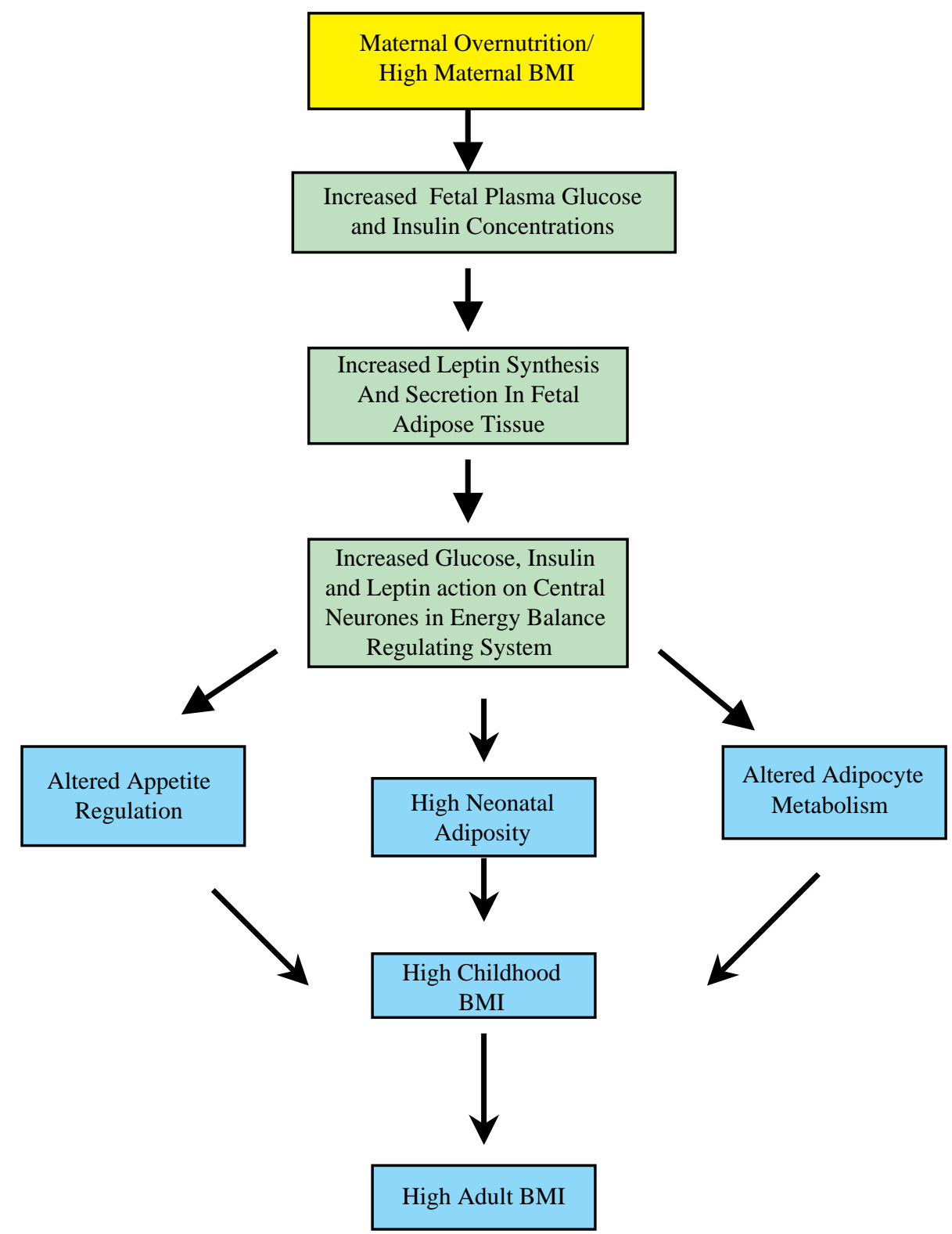

Figure 1 Potential pathways explaining the relationship between high birth weight and adult obesity.

subsequent fall in energy intake (Schwartz 2001). AgRP is an appetite stimulatory peptide that is coexpressed with NPY in the ARC nucleus and is an endogenous antagonist of the anorexigenic melanocortin receptors, MC3 and MC4R, in the paraventricular nucleus (PVN) and other hypothalamic regions. The POMC-derived peptide, $\alpha$-melanocyte-stimulating hormone $(\mathrm{MSH})$, is an endogenous appetite inhibitor which acts at these melanocortin receptors to suppress food intake. Leptin increases POMC expression within the ARC nucleus which results in a decrease in energy intake (Schwartz 2001).

Resistance to the actions of leptin would result in a relative inability of high circulating leptin concentrations to suppress appetite and increase energy utilisation (Ahima
\& Flier 2000). Adult obesity is associated with relatively high circulating leptin concentrations and the tendency to gain weight in some non-obese populations that have relatively high basal leptin concentrations may indicate an underlying role for leptin resistance in obesity (Chessler et al. 1998, Lindroos et al. 1998, Lissner et al. 1999). It has been suggested that elevated circulating leptin concentrations result in an uncoupling of the action of leptin at its receptors in the hypothalamus, thereby disrupting signal transduction pathways that are required for appetite suppression (Kieffer et al. 1996, Ahima \& Flier 2000). The presence of functional leptin receptors on pancreatic $\beta$ cells and the observation that leptin directly inhibits insulin secretion also led to the concept of an 'adipoinsular 


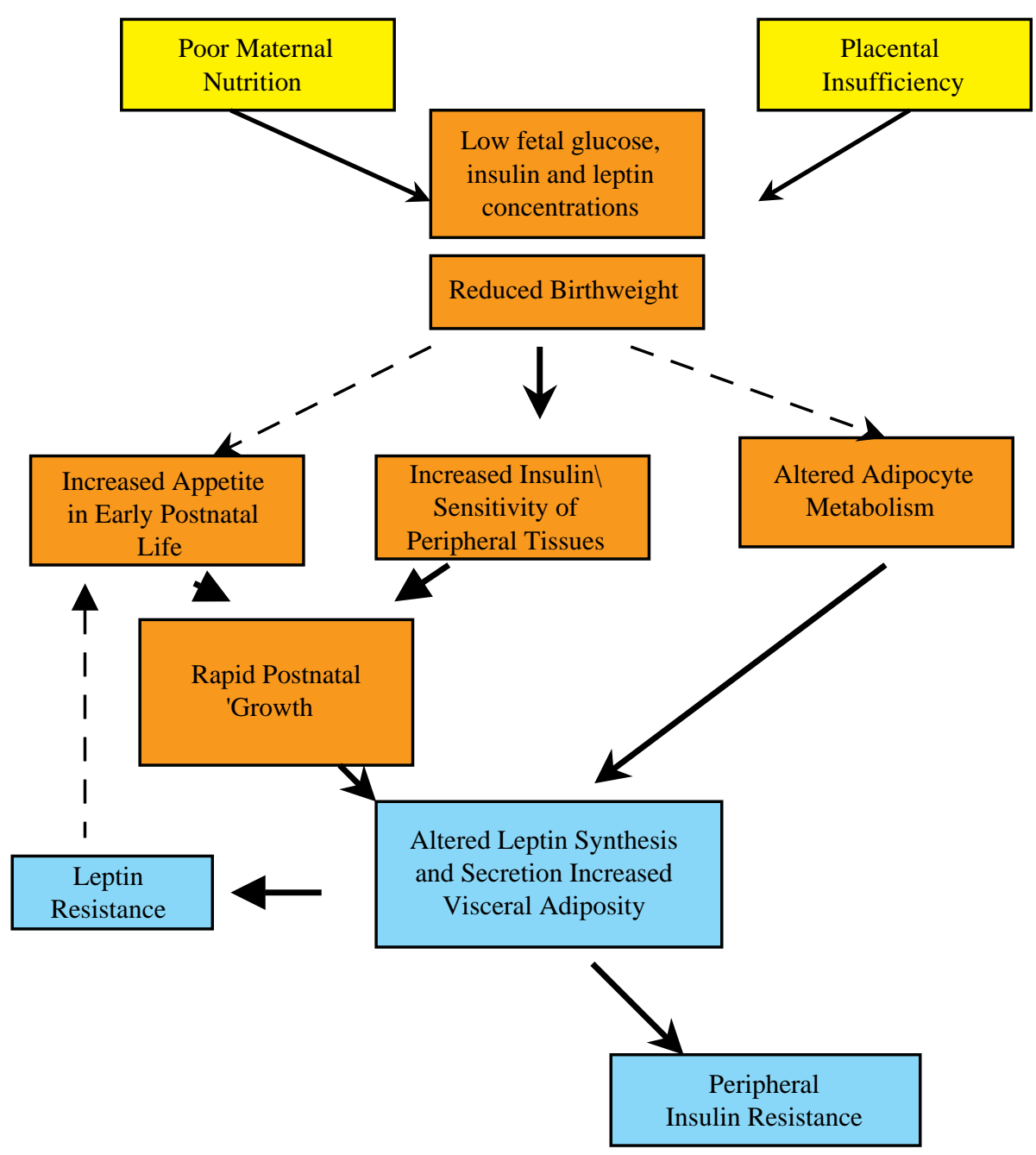

Figure 2 Potential pathways explaining the relationship between low birth weight, visceral adiposity and insulin resistance.

axis' (Kieffer \& Habener 2000) whereby insulin stimulates adipogenesis and the synthesis of leptin, and leptin in turn inhibits the production of insulin in the pancreas. It has been proposed that pancreatic leptin resistance may be a mechanism underlying the hyperinsulinism frequently associated with obesity and that it may contribute to the subsequent development of diabetes in obese individuals (Seufert et al. 1999).

\section{Leptin synthesis and secretion before birth}

In rodents, the capacity of fetal adipocytes to synthesise leptin is relatively limited until late in gestation and, while the placenta synthesises little if any leptin (Kawai et al. 1997, Amico et al. 1998), there is significant transplacental transfer of maternal leptin to the fetus. This transfer increases during late pregnancy in parallel with an upregulation of expression of the shorter isoforms of the leptin receptor in the placenta (Smith \& Waddell 2002, 2003).

In species such as the sheep and pig, in which fat is deposited before birth, leptin is synthesised in fetal adipose tissue and is present in the fetal circulation through late gestation (Yuen et al. 1999, Chen et al. 2000, Devaskar et al. 2002, Ehrhardt et al. 2002, Muhlhausler et al. 2002, 2003, Yuen et al. 2002). Leptin is also expressed in the fetal sheep brain and liver but, in contrast to the human, leptin is not expressed in the sheep placenta (Thomas et al. 2001, Ehrhardt et al. 2002). Leptin is present in the circulation of the sheep fetus from as early as 40 days gestation, which is before the development of visible adipose tissue depots, and fetal plasma leptin may therefore originate from either the maternal circulation or from fetal tissues other than adipose tissue at this early stage of pregnancy (Ehrhardt et al. 2002). Circulating leptin concentrations are lower in the fetus than in the pregnant ewe throughout late gestation (Ehrhardt et al. 2002, Muhlhausler et al. 2002, Yuen et al. 2002). It has been reported that the sheep placenta expresses the leptin receptor gene (Thomas et al. 2001) and, as maternal and fetal plasma leptin concentrations are positively correlated throughout late gestation (Yuen et al. 2002), it is possible 
that in the sheep the placental leptin receptor may mediate the uptake of leptin from the maternal into the fetal circulation. There has been a recent report, however, that the leptin receptor is not expressed in the sheep placenta (Bispham et al. 2003) and maternal body composition or fatness either at the beginning or during pregnancy may therefore determine the leptin synthetic and secretory capacity of both maternal and fetal adipose tissue. Importantly, there is also a positive relationship between the relative abundance of leptin mRNA in fetal perirenal adipose tissue (which comprises $>80 \%$ of the fetal fat mass) and fetal plasma leptin concentrations (Yuen et al. 2002). It has been reported in the South Australian Merino ewe that fetal plasma leptin concentrations do not vary significantly during late gestation or during the period immediately before birth (Yuen et al. 2004); whereas in the Welsh Mountain ewe there is an increase in circulating leptin concentrations in the fetus at 130-140 days gestation (Forhead et al. 2002). Interpretation of differences in baseline plasma leptin concentrations in ruminants is also complicated to some extent by the use of different assays, which appear to provide different values for leptin in animals in the same body weight and body condition range (Chilliard et al. 2001).

Ultrastructural studies of adipose tissue in the sheep fetus have demonstrated that fetal adipocytes contain multiple lipid locules and an abundance of mitochondria, and express uncoupling protein 1 (UCP1): characteristic features of thermogenic or brown adipose tissue (Gemmell et al. 1972, Gemmell \& Alexander 1978, Symonds \& Stephenson 1999, Yuen et al. 2003). Fetal adipocytes also contain larger or dominant lipid locules and there is a direct relationship between the relative mass of the 'unilocular' component of perirenal and interscapular fat, and circulating leptin concentrations in a cohort of fetuses in well-nourished pregnant ewes (Muhlhausler et al. 2002). This suggests that circulating leptin concentrations may be a signal of the unilocular component of fetal fat, rather than total fat mass in fetal life, as it is in the neonate and adult.

\section{Maternal undernutrition and the regulation of maternal and fetal plasma leptin concentrations}

In sheep, the impact of maternal undernutrition on plasma leptin concentrations appears to be dependent on the breed and age of the ewe and on the level of nutrient restriction. In growing adolescent ewes (Suffolk or Dorset Horn $\times$ Greyface; body weight $40-45 \mathrm{~kg}$ ) pregnant as a result of embryo transfer, increases or decreases in maternal nutrition during the first 100 days of gestation were associated with parallel increases or decreases in maternal plasma leptin concentrations (Thomas et al. 2001). In this study, when data were pooled across nutritional treatments, circulating leptin concentrations at 104 days gestation were positively correlated with maternal weight and body condition score. A 40\% restriction of metabolisable energy (ME) requirements between 28 and 80 days gestation also resulted in a decrease in maternal leptin concentrations in Welsh Mountain ewes (body weight $35-40 \mathrm{~kg}$ ) (Bispham et al. 2003); whereas a $50 \%$ restriction from 115 days gestation resulted in a fall in plasma glucose, but not leptin, concentrations in Merino ewes (body weight 50-60 kg) during late gestation (Yuen et al. 2002). Similarly, in a study in which Merino ewes were undernourished from day 8 of pregnancy, plasma glucose, but not leptin, concentrations were lower in singleton-bearing ewes (Edwards et al. 2005). Thus in large adult ewes carrying singleton fetuses, maternal leptin concentrations are not as sensitive a measure of the level of prevailing nutrition as maternal glucose concentrations. In the latter study, however, there was a significant relationship between maternal plasma leptin and glucose concentrations during late gestation when all nutritional groups (including ewes exposed to restricted nutrition from before pregnancy until 7 days after mating only, from 8 to 145 days gestation inclusive and from before pregnancy until 145 days gestation) were combined. Interestingly in ewes carrying twin pregnancies, while maternal plasma leptin concentrations were not lower in ewes exposed to undernutrition during late gestation, they were directly related to the amount of weight loss experienced before pregnancy when nutrition treatment groups were combined. As there is a greater energy demand on the mother during a twin pregnancy, it is not surprising that relationships between the level of maternal leptin during late gestation and changes in pre-pregnancy weight emerge in ewes carrying twins. In contrast to ewes carrying singletons, there was no direct relationship between maternal plasma leptin and glucose concentrations in ewes carrying twins during late gestation - presumably reflecting the greater dependence of maternal leptin concentrations in late gestation on the body fat stores at the start of pregnancy in these animals. These results highlight the interaction between the amount of body fat stores at the start of pregnancy, the number of fetuses and the level of nutrient intake throughout pregnancy in determining circulating leptin concentrations in the pregnant ewe.

It has been reported that there is no impact of maternal undernutrition, imposed during either the periconceptional period or throughout gestation, on fetal plasma leptin concentrations during late gestation (Edwards et al. 2005). Previous studies also reported that an $\sim 50 \%$ decrease in maternal nutrient intake in late gestation did not decrease fetal plasma concentrations of leptin or the relative abundance of leptin mRNA in perirenal adipose tissue in the fetal sheep (Ehrhardt et al. 2002, Yuen et al. 2002). Thus the synthesis and secretion of leptin in the sheep fetus appears relatively resistant to the changes in fetal glucose and insulin concentrations associated with moderate maternal undernutrition. Interestingly, while there was no difference in fetal plasma leptin concentrations in ewes undernourished at different windows of early and late gestation, there was a relative increase in adiposity in twin 
fetuses of ewes exposed to maintenance nutrition before pregnancy and for 1 week after conception followed by a decrease in nutrition for the remainder of pregnancy (Edwards et al. 2005). Fetal adiposity was not increased in those ewes that had been undernourished from before and throughout pregnancy. This suggests that adiposity may be programmed in twin fetal sheep as a consequence of changes in the plane of maternal nutrition during early pregnancy. The altered fetal fat deposition is unlikely to reflect the increased metabolic demand of twin fetuses, as the change in the level of nutrition occurred at a time when the metabolic demands of the embryos were minimal. It has been shown, however, that manipulation of the early nutritional environment of the embryo, either in vivo or in vitro, can alter the allocation of cells within the inner cell mass and trophectoderm, and subsequent fetal somatic and organ growth (Kwong et al. 2000). Maternal hormonal or metabolic responses to the change in the level of nutrition at the end of the first week of pregnancy may act to alter the expression of key genes within the developing blastocyst to result in enhanced adiposity in late gestation. Bispham and colleagues (2003) reported that there was an increase in relative fetal adiposity in fetuses in ewes that had been nutrient restricted between 28 and 80 days gestation and then fed to appetite (i.e. 150\% ME requirements) until 140 days gestation when compared with fetuses in ewes that had been fed to appetite between 28 and 140 days gestation. In this latter study, fetuses of ewes that had been nutrient restricted between 28 and 80 days gestation and then fed to energy requirements (100\% ME) did not have an increase in relative adiposity when compared with their control counterparts, although there was an increase in insulin-like growth factor (IGF)-1R and IGF2-R mRNA levels in fetal adipose tissue at 140 days (Bispham et al. 2003). It appears therefore that there are different critical windows during which the imposition of maternal undernutrition ( $\sim 8$ days gestation) or maternal overnutrition ( $\sim 80$ days gestation) can result in an increased fetal adiposity. While nutrient restriction between 28 and 80 days gestation did not result in a change in leptin mRNA expression in fetal adipose tissue, there was a decrease in leptin mRNA abundance in fetal adipose tissue at 140 days gestation in ewes that were fed on a high nutritonal plane from 80 days gestation (Bispham et al. 2003). Future studies are clearly required to determine the interactions between maternal nutrition, fetal adiposity, the IGFs, leptin and other adipocyte-derived hormones in the programming of postnatal obesity in animals in which fat is deposited and leptin is expressed within fat depots before birth.

\section{Maternal overnutrition and the regulation of maternal and fetal plasma leptin concentrations}

In the sheep, a moderate increase $(\sim 50 \%)$ in maternal nutrient intake above maintenance requirements increases maternal plasma glucose and leptin concentrations during late gestation in the absence of a concomitant increase in either total fetal fat mass or fetal plasma leptin concentrations (Muhlhausler et al. 2002). In these well-nourished ewes there was, however, a significant relationship between fetal glucose and the relative mass of fetal unilocular fat, and a positive relationship between fetal insulin concentrations and the relative abundance of leptin mRNA in fetal perirenal adipose tissue (Muhlhausler et al. 2003). Insulin-responsive elements have been identified within the promoter of the leptin gene in the adult mouse and insulin upregulates leptin gene transcription in adipocytes of adult rodents (Saladin et al. 1995). A moderate increase in maternal nutrition also resulted in a strong reciprocal relationship between leptin and UCP1 expression in fetal perirenal adipose tissue in late gestation.

In a model that mimics the effects of a diabetic pregnancy and the associated fetal hyperglycaemia, infusion of glucose directly to the sheep fetus for 10 days in late gestation resulted in an increase in the size of the dominant lipid locules and in the total mass of unilocular perirenal adipose tissue in the fetus (Muhlhausler et al. 2005). The mean lipid locule size was also directly related to fetal glucose, but not insulin, concentrations during the infusion period in the saline- and the glucose-infused fetuses. This is consistent with the finding of a similar relationship between glucose concentrations and lipid locule size in the fetal adipose tissue of the well-nourished ewe (Muhlhausler et al. 2003), and suggests that glucose, rather than insulin, is the principal determinant of lipid storage in fetal adipocytes during late gestation. This is supported by previous reports that the abundance of the insulin-independent glucose transporter (GLUT1) is greater than that of the insulindependent glucose transporter (GLUT4) in the adipose tissue of the sheep fetus in late gestation (Das et al. 1998).

While a 10-day glucose infusion resulted in an increase in lipid locule size, it did not result in a significant increase in relative adiposity in the fetal sheep. It has previously been reported that a 30-day infusion of glucose in fetal sheep increased total fetal fat mass (Stevens et al. 1990). It may be that the fetus is able to adapt to 10 days of glucose infusion, but not to a more prolonged period of hyperglycaemia, through mechanisms that limit the impact of an increase in fetal glucose on fetal adiposity. Prolonged fetal hyperglycaemia is associated with a decline in adipose GLUT-1 levels in the sheep fetus (Das et al. 1999); this may be one mechanism that acts to counter a chronic increase in fetal nutrient supply. As in the well-nourished ewe, while leptin expression in fetal adipose tissue was not increased in glucose-infused fetuses, there was a strong positive relationship between either plasma insulin or glucose concentrations and leptin mRNA expression in fetal adipose tissue in these fetuses. Infusions of glucose resulting in prolonged periods (14-20 days) of hyperglycaemia and hyperinsulinaemia, however, do increase fetal fat mass (Stevens et al. 1990) and leptin mRNA abundance in fetal perirenal adipose tissue (Devaskar et al. 2002) Thus, while leptin synthesis is not 
upregulated in the presence of moderate maternal overnutrition or a 10-day intrafetal infusion of glucose, there is evidence of a positive relationship between circulating insulin concentrations and the level of leptin expression in these fetuses. This suggests that within a 'moderate' range of fetal plasma glucose and insulin concentrations, there may be active counter-regulatory mechanisms present within the fetus to limit the potential impact of fetal overnutrition on leptin synthesis and secretion, and these mechanisms may be overwhelmed in the presence of excessive glucose or insulin exposure.

\section{Actions of leptin in the fetus}

There is evidence that leptin may have a range of neuroendocrine and endocrine actions in the sheep fetus. Intrafetal leptin infusion, resulting in a 4 - to 5 -fold increase in circulating leptin concentrations suppressed the normal prepartum increase in fetal cortisol concentrations for an extended period from 90 to $42 \mathrm{~h}$ before delivery but did not alter the timing of parturition in these animals (Yuen et al. 2004). Intrafetal leptin infusion in the presence of normoglycaemia and normoinsulinaemia also results in an increase in the proportion of multilocular tissue and a decrease in the proportion and relative mass of unilocular tissue in the perirenal adipose depot; the relative abundance of leptin mRNA in perirenal adipose tissue was also lower in leptin-infused fetuses and, in addition, there was a strong correlation between the proportion of unilocular fat and leptin mRNA expression in this tissue (Yuen et al. 2003). These findings suggest that leptin may act as a signal of energy supply and have a 'lipostatic' role before birth (Fig. 3). The extent to which leptin can act on the central neural network which normally regulates appetite in adult life, is clearly dependent on the extent to which this network is present before birth.

\section{Development of the appetite regulatory system before birth}

In the rat brain, neurones expressing the appetite regulatory peptides develop in the hypothalamus at around 14.5 days gestation (term $\approx 21$ days) and NPY mRNA expression rapidly increases during the first 2 weeks after birth (Grove \& Smith 2003). POMC, AgRP and MC4R mRNA are also all present within the rat hypothalamus during this neonatal period. While NPY is present in the ARC nucleus from late gestation, connections between this nucleus and other hypothalamic nuclei that act to regulate appetite are not complete until 2 weeks of age (Grove \& Smith 2003).

In contrast to the rodent, NPY has been found to be present from as early as 21 weeks gestation in the human hypothalamus and at this stage there are already projec-

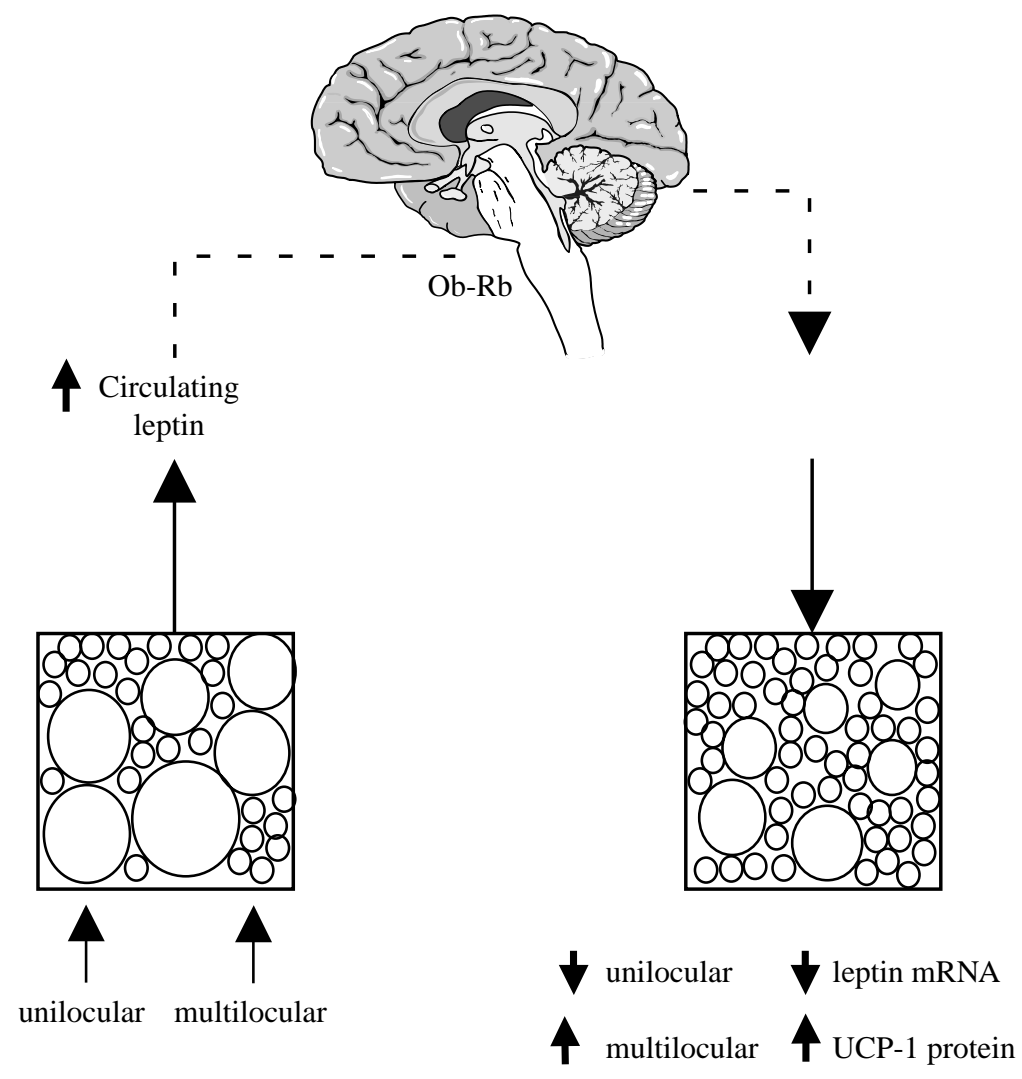

Fetal Adipose Tissue
Figure 3 Schematic diagram representing a summary of the potential effects of an increase in circulating leptin concentrations on the structural and functional characteristics of fetal adipose tissue (reprinted from Yuen et al. (2003)). It is speculated that leptin secreted by the unilocular component of fetal adipose tissue activates the long form of the leptin receptor $(\mathrm{OB}-\mathrm{Rb})$ in the fetal hypothalamus. This results in a stimulation of the sympathetic nervous system, an increase in lipolysis and an associated decrease in the size of the lipid locules within the unilocular component of the fetal adipose tissue. The decrease in the proportion of the unilocular adipose tissue results in a decrease in the relative abundance of leptin mRNA in this tissue. 
tions between the ARC nucleus and the PVN (Koutcherov et al. 2002). It is therefore possible that in the human, nutritional or hormonal exposure during fetal or early neonatal life may be important in determining the subsequent development of the appetite regulatory system. We have also previously reported that genes for the appetite-regulating neuropeptides - NPY, AgRP, POMC and CART are each expressed in the ARC nucleus of the fetal sheep hypothalamus by 110 days gestation (term $=147 \pm 3$ days gestation) (Muhlhausler et al. 2004). The long form of the leptin receptor (OB-Rb) is also expressed in both the ARC and ventromedial nucleus (VMN) of the fetal sheep, and to a lesser extent in the dorsomedial nucleus (DMN), consistent with the reported pattern of expression in the adult sheep (Williams et al. 1999, Muhlhausler et al. 2004). While the sites of OB-Rb expression were similar in the fetal and adult sheep, there were differences in the relative intensity of hybridisation within these hypothalamic nuclei (Fig. 4) Specifically, the intensity of OB-Rb expression was higher in the $\mathrm{VMN}$ compared with the ARC nucleus in fetal sheep whereas in the adult hypothalamus, the ARC nucleus is the predominant site of expression of the OB-Rb (Muhlhausler et al. 2004). In the adult rodent, the $\mathrm{VMN}$ has been implicated as being important for the regulation of thermogenesis in the brown adipose tissue and the higher level of OB-Rb expression in the fetal VMN may indicate that leptin has a greater role in the regulation of the thermogenic activity of brown adipose tissue, rather than 'energy intake', during the perinatal period. In this species it has also recently been demonstrated that intrafetal infusion of glucose in late gestation resulted in a significant increase in POMC mRNA in the ARC nucleus of the fetal sheep hypothalamus (Muhlhausler et al. 2005). This occurred in the absence of an increase in circulating leptin, indicating that during fetal life, POMC mRNA expression in the hypothalamus may be responsive to increases in glucose or insulin, acting either alone or in combination. Interestingly, there was no effect of intrafetal glucose infusion on the expression of the orexigenic neuropeptides NPY and AgRP in the fetal sheep hypothalamus (Muhlhausler et al. 2005). This is surprising given that circulating glucose and insulin concentrations in the fetus are relatively low compared with those measured in adult life and that fetal hypothalamic NPY content is increased following maternal undernutrition in sheep (Warnes et al. 1998). There have been no reports to date of the impact of intrafetal leptin administration on the expression of the appetite regulatory peptides within the fetal hypothalamus. Clearly, further work is required to determine whether there is a critical window during which exposure of the fetal brain to relatively low or high leptin concentrations results in an altered development of the energy balance regulating system within the hypothalamus that persists into postnatal and adult life. In this context it has been demonstrated that low birth weight lambs have a higher relative voluntary food intake during the early postnatal period and are fatter at body weights up to $20 \mathrm{~kg}$ when compared with lambs with normal birth weights (Greenwood et al. 1998); however, there is no information on whether this relative hyperphagia is a result of an early programming of the appetite regulatory neuropeptides.

\section{Leptin and the early programming of adult obesity}

The role of leptin in the early programming of later obesity has been predominantly investigated in the rodent in a number of models in which the early nutritional experience has been manipulated. The most common manipulations of fetal nutrition in the rodent are through exposure of the pregnant dam to either a global undernutrition through a $30-50 \%$ reduction in energy intake or a low-protein diet (generally 9 vs $18 \%$ protein content). When rats are undernourished during the first 2 weeks of pregnancy but re-fed during the third week, the male offspring develop significant increases in appetite and obesity when maintained on a high-fat diet (Stephens 1980, Jones \& Friedman 1982, Anguita et al. 1993, Jones et al. 1996). When maternal nutrition is restricted to $30 \%$ of control intake throughout the whole of gestation, while the offspring were smaller throughout postnatal life, there was an increase in the relative mass of the retroperitoneal fat pad in these animals at 100 days of age (Vickers et al. 2000). Food intake in the offspring of the undernourished rats (cross-fostered on to ad libitum-fed mothers) was increased early in postnatal life, increased with increasing age and was amplified by postnatal hypercaloric nutrition (Vickers et al. 2000).

When leptin is administered to pregnant dams on days 8 , 10 and 12 of pregnancy, the adult offspring have reduced adipose tissue mass and skeletal growth with no change in food intake (Nilsson et al. 2003). Maternal protein restriction results in a significant decrease in maternal, but not fetal, leptin concentrations during late gestation (Fernandez-Twinn et al. 2003). Administration of leptin to pregnant rats fed a low-protein diet prevented the diet-induced fall in the activity of the placental enzyme, $11 \beta$ hydroxysteroid dehydrogenase 2 , which normally protects the fetus from excess glucocorticoid exposure (Stocker et al. 2004). In these experiments, the male offspring of saline-treated dams gained more weight and had higher plasma leptin levels when transferred to a high-fat diet at 6 weeks, but the offspring of leptin-treated dams did not show this phenotype (Stocker et al. 2004). This may be an example of where an experimental induction of an increase in maternal leptin (normally associated with an increase in body fat) programs the ability of the offspring to respond better to a high-fat diet in the postnatal period. This fits with the concept of a maternal 'adaptive' response to overnutrition with the dam programming the subsequent development of her fetus to respond appropriately to an increase in nutrition in postnatal life.

In contrast, exposure of rats to maternal undernutrition (30\% energy intake) during gestation leads to an increase in 

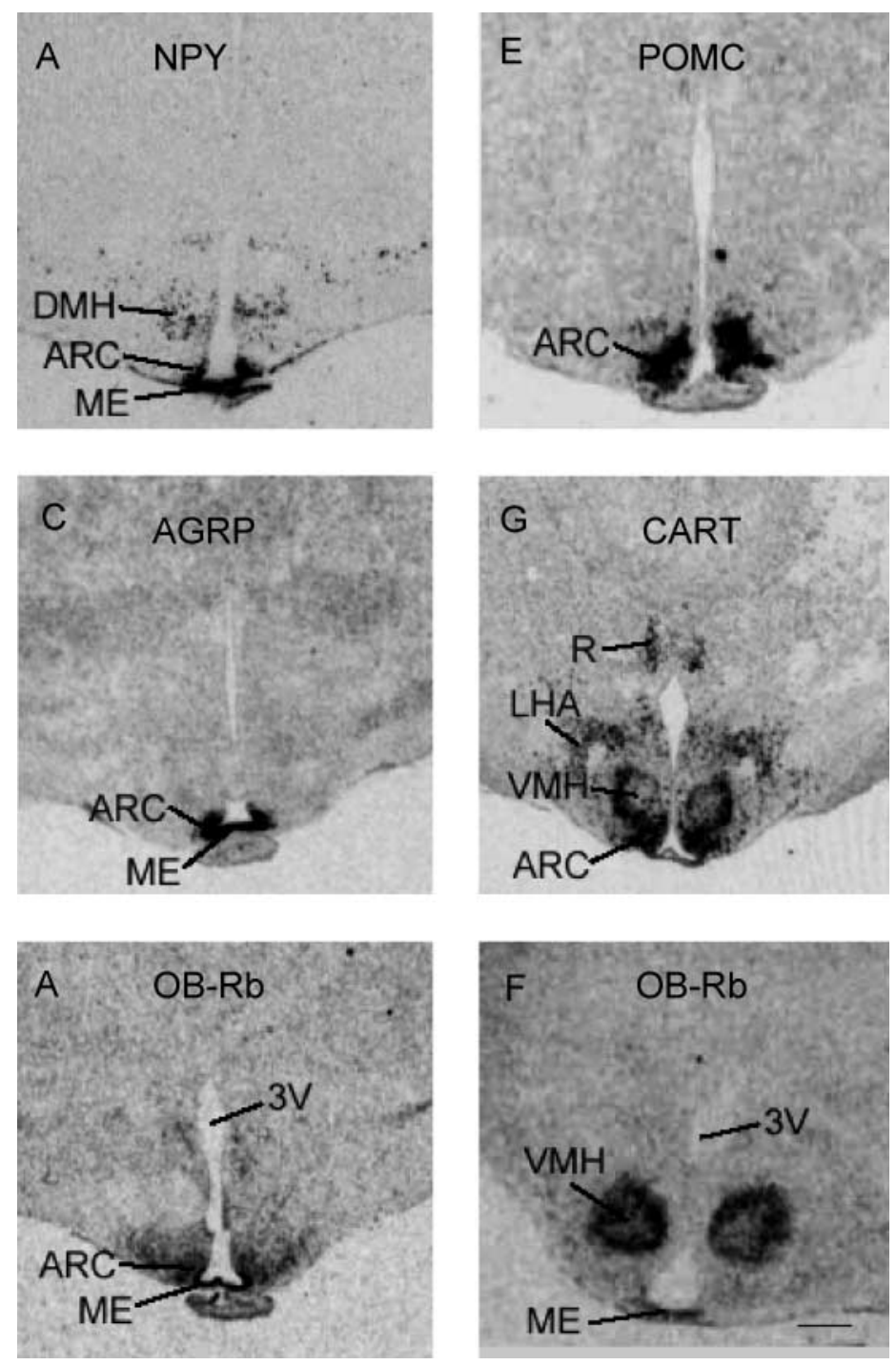

Figure 4 Autoradiographic images of coronal sections through fetal sheep hypothalamus at 110 days gestation (term $\approx 147$ days) showing gene expression for NPY, AgRP, POMC, CART and leptin receptor $(\mathrm{OB}-\mathrm{Rb})$ (reprinted from Muhlhausler et al. (2004)). ARC, arcuate nucleus; ME, median eminence; VMH, ventromedial hypothalamus; $\mathrm{DMH}$, dorsomedial hypothalamus; PVN, paraventricular nucleus; $R$, reuniens thalamic nucleus; OC, optic chiasm; 3V, 3rd ventricle; LHA, lateral hypothalamic area. relative adiposity and high circulating leptin concentrations in adult offspring (Vickers et al. 2000). The combination of prenatal undernutrition together with postnatal hypercaloric nutrition leads to a major amplification of the hyperleptinaemia. The hyperleptinaemia in the presence of hyperinsulinism in the offspring on the hypercaloric diet suggests that there may be development of leptin resistance both at the hypothalamus and the pancreas (Breier et al. 2001).

Thus, in the rat, manipulation of maternal plasma leptin concentrations by altering maternal nutrition, infusion of leptin to the dam or manipulation of transplacental leptin transfer has an impact on the subsequent regulation of leptin synthesis and secretion in the offspring in postnatal life. This impact appears to be dependent to a large extent on the fetal exposure to the maternal leptin signal as there is very limited development of endogenous leptin synthetic capacity before birth.

\section{Leptin and appetite regulation in the rodent in early life}

While the appetite regulatory system is relatively immature at birth in the rat, the amount of food consumed during the suckling period plays an important role in determining subsequent food intake in the rat (Oscai \& McGarr 1978). When postnatal overnutrition is induced in rats, by rearing in small litters of only three pups, they show an increased early weight gain and fat deposition, followed by an increased appetite (hyperphagia), obesity, hyperleptinaemia, hyperglycaemia, hyperinsulinaemia and insulin resistance (Plagemann et al. 1992, 1999). Leptin has a lower inhibitory effect on the appetite stimulatory neurones of the hypothalamus in these animals as young adults (Davidowa \& Plagemann 2000, 2001).

Interestingly, a recent study has reported that neural projection pathways from the ARC nucleus are perma- 
nently disrupted in leptin-deficient $\left(\operatorname{Lep}^{\mathrm{ob}} / \mathrm{Lep}^{\mathrm{ob}}\right)$ mice and that treatment of these mice with leptin in neonatal, but not in adult, life rescues the development of projections from the ARC nucleus (Bouret et al. 2004). Thus leptin acts to promote the development of hypothalamic pathways that will have a role in later life in regulating food intake and energy consumption. These actions of leptin appear to be specific to the neurones of the ARC nucleus and only occur during a critical window of time that corresponds to a neonatal period when leptin concentrations are usually high. This neonatal 'critical period' also corresponds to the period when the axons from the ARC neurones are guided to their targets (Bouret et al. 2004). Thus leptin derived from the maternal circulation, present in breast milk or derived from the neonatal adipocytes may exert an important influence on the development of the appetite regulatory neural network.

It is therefore possible that leptin in the fetal circulation derived either from the maternal circulation (as in the rat in late gestation and potentially the sheep in early gestation) or fetal adipose tissue (as in the sheep and human in late gestation) acts centrally via leptin receptors located on neurones within the fetal hypothalamus to have a 'lipostatic' role. While leptin may play a role in regulating the structural and functional characteristics of the developing adipocyte in utero, it is also possible that exposure to high or low leptin concentrations during critical windows of development of the neural network that regulates appetite may have longer term consequences for this network and for the regulation of energy balance after birth.

\section{Summary}

There is substantial evidence from epidemiological studies that being of high birth weight, or being of low birth weight and growing rapidly in postnatal life, can each be associated with an increased BMI or an increased visceral adiposity in later life. There is also evidence to indicate that maternal body composition and the level of maternal nutrition may contribute to the programming of obesity in her offspring. While there has been a predominant focus in this field on the impact of poor fetal nutrition on subsequent body composition in adult life, there is a growing awareness of the potential for an intergenerational cycle of obesity as women enter pregnancy with a higher BMI and then have heavier babies who may then be programmed to be heavy in adult life (Kral 2004). There have been many reports, predominantly in the rodent, demonstrating that the nutritional environment in early life can have a lifelong impact on the distribution and amount of body fat mass. It is only relatively recently, however, that the role of specific nutrients and hormones, such as leptin, in the early programming of postnatal obesity has begun to be defined. In the rodent, it is now becoming clear that the maternal nutrient and leptin concentrations may provide the fetal and neonatal rat with key signals of the current, and poten- tially the future, nutrient environment. In species such as the human and sheep, there is also recent evidence that the synthesis and secretion of adipocyte-derived hormones, such as leptin, are regulated in fetal life; there is also evidence that the hypothalamic neuropeptides which regulate energy intake and expenditure in adult life are also present within the fetal brain and may be regulated by the prevailing level of maternal and hence fetal nutrient and hormonal signals, including leptin. This work is of importance in determining those initiating mechanisms within the 'fatbrain' axis in early life that precede the development of adult obesity and the critical windows during which intervention will have maximum benefit to ensure a lifelong resilience to an increased body fat mass.

\section{References}

Ahima RS \& Flier JS 2000 Adipose tissue as an endocrine organ. Trends in Endocrinology and Metabolism 11 327-332.

Amico JA, Thomas A, Crowley RS \& Burmeister LA 1998 Concentrations of leptin in the serum of pregnant, lactating, and cycling rats and of leptin messenger ribonucleic acid in rat placental tissue. Life Science 63 1387-1395.

Anguita RM, Sigulem DM \& Sawaya AL 1993 Intrauterine food restriction is associated with obesity in young rats. Journal of Nutrition 123 1421-1428.

Bavdekar A, Yajnik C, Fall C, Bapat S, Pandit A, Deshpande V, Bhave S, Kellingray S \& Joglekar C 1999 Insulin resistance syndrome in 8 -year-old Indian children: small at birth, big at 8 years, or both? Diabetes 48 2422-2429.

Bispham J, Gopalakrishnan GS, Dandrea J, Wilson V, Budge $\mathbf{H}$, Keisler DH, Broughton Pipkin F, Stephenson T \& Symonds ME 2003 Maternal endocrine adaptation throughout pregnancy to nutritional manipulation: consequences for maternal plasma leptin and cortisol and the programming of fetal adipose tissue development. Endocrinology 144 3575-3585.

Bouret SG, Draper SJ \& Simerly RB 2004 Trophic action of leptin on hypothalamic neurons that regulate feeding. Science 304 $108-110$

Breier BH, Vickers MH, Ikenasio BA, Chan KY \& Wong WPS 2001 Fetal programming of appetite and obesity. Molecular and Cellular Endocrinology $18573-79$.

Campfield LA, Smith FJ \& Burn P 1998 Strategies and potential molecular targets for obesity treatment. Science 280 1383-1387.

Cetin I, Morpurgo PS, Radelli T, Taricco E, Cortelazzi D, Bellotti M, Pardi G \& Beck-Peccoz P 2000 Fetal plasma leptin concentrations: relationship with different intrauterine growth patterns from 19 weeks to term. Pediatric Research 48 646-651.

Chen X, Lin J, Hausman DB, Martin RJ, Dean RG \& Hausman GJ 2000 Alterations in fetal adipose tissue leptin expression correlate with the development of adipose tissue. Biology of the Neonate $\mathbf{7 8}$ $41-47$.

Chessler SD, Fujimoto WY, Shofer JB, Boyko EJ \& Weigle DS 1998 Increased plasma leptin levels are associated with fat accumulation in Japanese Americans. Diabetes 47 239-243.

Chilliard Y, Bonnet M, Delavaud C, Faulconnier Y, Leroux C, Djiane J \& Bocquier F 2001 Leptin in ruminants. Gene expression in adipose tissue and mammary gland, and regulation of plasma concentration. Domestic Animal Endocrinology 4 271-295.

Curhan GC, Chertow GM, Willett WC, Spiegelman D, Colditz GA, Manson JE, Speizer FE \& Stampfer MJ 1996a Birth weight and adult hypertension and obesity in women. Circulation 94 1310-1315. 
Curhan GC, Willett WC, Rimm EB, Spiegelman D, Ascerio AL \& Stampfer MJ $1996 b$ Birth weight and adult hypertension, diabetes mellitus and obesity in US men. Circulation 94 3246-3250.

Das UG, Sadiq F, Soares MJ, Hay WW \& Devaskar SU 1998 Timedependent physiological regulation of rodent and ovine placental glucose transporter (GLUT-1) protein. American Journal of Physiology 274 R339-R347.

Das UG, Schroeder RE, Hay WWJ \& Devaskar SU 1999 Time-dependent and tissue specific effects of circulating glucose on fetal ovine glucose transporters. American Journal of Physiology $\mathbf{2 7 6}$ R809-R817.

Davidowa H \& Plagemann A 2000 Different responses of ventromedial hypothalamic neurons to leptin in normal and early postnatally overfed rats. Neuroscience Letters $29321-24$.

Davidowa H \& Plagemann A 2001 Inhibition by insulin of hypothalamic VMN neurons in rats overweight due to postnatal overfeeding. Neuroreport 12 3201-3204.

Devaskar SU, Anthony R \& Hay W Jr 2002 Ontogeny and insulin regulation of fetal ovine white adipose tissue leptin expression. American Journal of Physiology, Regulation, Integration and Comparative Physiology 282 R431-R438.

Dorner G \& Plagemann A 1994 Perinatal hyperinsulinism as possible predisposing factor for diabetes mellitus, obesity and enhanced cardiovascular risk in later life. Hormones and Metabolic Research 26 213-221.

Edwards LJ, McFarlane JR, Kauter KG \& McMillen IC 2005 Impact of periconceptional nutrition on maternal and fetal leptin and fetal adiposity in singleton and twin pregnancies. American Journal of Physiology, Regulation, Integration and Comparative Physiology 288 R39-R45.

Ehrhardt RA, Bell AW \& Boisclair YR 2002 Spatial and developmental regulation of leptin in fetal sheep. American Journal of Physiology, Regulation, Integration and Comparative Physiology 282 R1628-R1635.

Eriksson JG, Forsen T, Tuomilehto J, Jaddoe VW, Osmond C \& Barker DJ 2002 Effects of size at birth and childhood growth on the insulin resistance syndrome in elderly individuals. Diabetologia 45 342-348.

Fall CHD, Osmond C, Barker DJP, Clark PMS, Hales CN, Stirling Y \& Meade TW 1995a Fetal and infant growth and cardiovascular risk factors in women. British Medical Journal $310428-432$.

Fall CHD, Vijayakumar M, Barker DJP, Osmond C \& Duggleby S $1995 b$ Weight in infancy and prevalence of coronary heart disease in adult life. British Medical Journal 310 17-19.

Fernandez-Twinn DS, Ozanne SE, Ekizoglou S, Doherty C, James L, Gusterson B \& Hales CN 2003 The maternal endocrine environment in the low-protein model of intra-uterine growth restriction. British Journal of Nutrition 90 815-822.

Flegal KM, Carroll MD, Ogden CL \& Johnson CL 2002 Prevalence and trends in obesity among US adults, 1999-2000. Journal of the American Medical Association 288 1723-1727.

Forhead AJ, Thomas L, Crabtree J, Hoggard N, Gardner DS, Giussani DA \& Fowden AL 2002 Plasma leptin concentration in fetal sheep during late gestation: ontogeny and effect of glucocorticoids. Endocrinology 143 1166-1173.

Friedman JM \& Halaas JL 1998 Leptin and the regulation of body weight in mammals. Nature $395763-770$.

Gemmell RT \& Alexander G 1978 Ultrastructural development of adipose tissue in foetal sheep. Australian Journal of Biological Science 31 505-515.

Gemmell RT, Bell AW \& Alexander G 1972 Morphology of adipose cells in lambs at birth and during subsequent transition of brown to white adipose tissue in cold and in warm conditons. American Journal of Anatomy 133 143-164.

Greenwood PL, Hunt AS, Hermanson JW \& Bell AW 1998 Effects of birth weight and postnatal nutrition on neonatal sheep: I. Body growth and composition, and some aspects of energetic efficiency. Journal of Animal Science 76 2354-2367.

Grove KL \& Smith MS 2003 Ontogeny of the hypothalamic neuropeptide Y system. Physiological Behaviours 79 47-63.
James WP 1996 The epidemiology of obesity. Ciba Foundation Symposium 201 1-11.

Jaquet D, Leger J, Levy-Marchal C, Oury JF \& Czernichow P 1998 Ontogeny of leptin in human fetuses and newborns: effect of intrauterine growth retardation on serum leptin concentrations. Journal of Clinical Endocrinology and Metabolism 83 1243-1246.

Jaquet D, Leger J, Tabone MD, Czernichow P \& Levy Marchal C 1999 High serum leptin concentrations during catch-up growth of children born with intrauterine growth retardation. Journal of Clinical and Endocrinological Metabolism 84 1949-1953.

Jones AP \& Friedman MI 1982 Obesity and adipocyte abnormalities in offspring of rats undernourished during pregnancy. Science $\mathbf{2 1 5}$ $1518-1519$.

Jones AP, Assimon SA \& Friedman MI 1996 The effect of diet on food intake and adiposity in rats made obese by gestational undernutrition. Physiological Behaviours 37 381-386.

Kawai M, Yamaguchi M, Murakami T, Shima K, Murata Y \& Kishi K 1997 The placenta is not the main source of leptin production in pregnant rat: gestational profile of leptin in plasma and adipose tissues. Biochemical and Biophysical Research Communications 240 798-802.

Kieffer TJ \& Habener JF 2000 The adipoinsular axis: effects of leptin on pancreatic beta-cells. American Journal of Physiology, Endocrinology and Metabolism 278 E1-E14.

Kieffer TJ, Heller RS \& Habener JF 1996 Leptin receptors expressed on pancreatic beta-cells. Biochemical and Biophysical Research Communications $224522-527$.

Koistinen HA, Koivisto VA, Andersson S, Karonen SL, Kontula K, Oksanen L \& Teramo KA 1997 Leptin concentration in cord blood correlates with intrauterine growth. Journal of Clinical and Endocrinological Metabolism 82 3328-3330.

Koutcherov Y, Mai JK, Ashwell KW \& Paxinos G 2002 Organization of human hypothalamus in fetal development. Journal of Comparative Neurology 446 310-324.

Kral JG 2004 Preventing and treating obesity in girls and young women to curb the epidemic. Obesity Research 12 1539-1546.

Kwong WY, Wild AE, Roberts P, Willis AC \& Fleming TP 2000 Maternal undernutrition during the preimplantation period of rat development causes blastocyst abnormalities and programming of postnatal hypertension. Development 17 4195-4202.

Law CM, Barker DJP, Osmond C, Fall CHD \& Simmonds SJ 1992 Early growth and abdominal fatness in adult life. Journal of Epidemiology and Community Health 46 184-186.

Levy-Marchal C, Jaquet D \& Czernichow P 2004 Long term metabolic consequences of being born small for gestational age. Seminars in Neonatology 9 67-74.

Lindroos A, Lissner L, Carlsson B, Carlsson L, Torgerson J, Karlsson C, Stenlof K \& Sjostrom L 1998 Familial predisposition for obesity may modify the predictive value of serum leptin concentrations for long-term weight change in obese women. American Journal of Clinical Nutrition 67 1119-1123.

Lissner L, Karlsson C, Lindroos AK, Sjostrom L, Carlsson B, Carlsson L \& Bengtsson C 1999 Birth weight, adulthood BMI, and subsequent weight gain in relation to leptin levels in Swedish women. Obesity Research 7 150-154.

Loos RJ, Beunen G, Fagard R, Derom C \& Vlietinck R 2001a Birth weight and body composition in young adult men - a prospective twin study. International Journal of Obesity Related Metabolic Disorders 25 1537-1545.

Loos RJ, Fagard R, Beunen G, Derom C \& Vlietinck R 2001b Birth weight and blood pressure in young adults: a prospective twin study. Circulation 104 1633-1638.

Loos RJ, Beunen G, Fagard R, Derom C \& Vlietinck R 2002 Birth weight and body composition in young women: a prospective twin study. American Journal of Clinical Nutrition 75 676-682.

Maffeis C, Micciolo R, Must A, Zaffanello M \& Pinelli L 1994 Parental and perinatal factors associated with childhood obesity in north-east Italy. International Journal of Obesity Related Metabolic Disorders $18301-305$. 
Malina RM, Katzmarzyk PT \& Beunen G 1996 Birth weight and its relationship to size attained and relative fat distribution at 7 to 12 years of age. Obesity Research 4 385-390.

Matsuda J, Yokota I, lida M, Murakami T, Naito E, Ito M, Shima K \& Kuroda Y 1997 Serum leptin concentration in cord blood: relationship to birth weight and gender. Journal of Clinical and Endocrinological Metabolism 82 1642-1644.

Muhlhausler BS, Roberts CT, McFarlane JR, Kauter KG \& McMillen IC 2002 Fetal leptin is a signal of fat mass independent of maternal nutrition in ewes fed at or above maintenance energy requirements. Biology of Reproduction 67 493-499.

Muhlhausler BS, Roberts CT, Yuen BSJ, Marrocco E, Budge $\mathbf{H}$, Symonds ME, McFarlane JR, Kauter KG, Stagg P, Pearse JK \& McMillen IC 2003 Determinants of fetal leptin synthesis, fat mass, and circulating leptin concentrations in well-nourished ewes in late pregnancy. Endocrinology 144 4947-4954.

Muhlhausler BS, McMillen IC, Rouzaud G, Findlay PA, Marrocco EM, Rhind SM \& Adam CL 2004 Appetite regulatory neuropeptides are expressed in the sheep hypothalamus before birth. Journal of Neuroendocrinology $16502-507$.

Muhlhausler BS, Adam CL, Marrocco E, Findlay PA, Roberts CT, McFarlane JR, Kauter KG \& McMillen IC 2005 Impact of glucose infusion on the structural and functional characteristics of adipose tissue and on hypothalamic gene expression for appetite regulatory neuropeptides in the sheep fetus during late gestation. Journal of Physiology 565 185-195.

Nilsson C, Swolin-Eide D, Ohlsson C, Eriksson E, Ho HP, Bjorntorp P \& Holmang A 2003 Reductions in adipose tissue and skeletal growth in rat adult offspring after prenatal leptin exposure. Journal of Endocrinology 176 13-21.

Ogden CL, Flegal KM, Carroll MD \& Johnson CL 2002 Prevalence and trends in overweight among US children and adolescents, 19992000. Journal of the American Medical Association 288 1728-1732.

Okosun IS, Liao Y, Rotimi CN, Dever GE \& Cooper RS 2000 Impact of birth weight on ethnic variations in subcutaneous and central adiposity in American children aged 5-11 years. A study from the Third National Health and Nutrition Examination Survey. International Journal of Obesity Related Metabolic Disorders 24 479-484.

Oscai LB \& McGarr JA 1978 Evidence that the amount of food consumed in early life fixes appetite in the rat. American Journal of Physiology, Regulation, Integration and Comparative Physiology 235 R141-R144.

Parsons TJ, Power C \& Manor O 2001 Fetal and early life growth and body mass index from birth to early adulthood in 1958 British cohort: longitudinal study. British Medical Journal 323 $1331-1335$.

Phillips DIW, Fall CHD, Cooper C, Norman RJ, Robinson JS \& Owens PC 1999 Size at birth and plasma leptin concentrations in adult life. International Journal of Obesity Related Metabolic Disorders 23 1025-1029.

Plagemann A, Heidrich I, Gotz F, Rohde W \& Dorner G 1992 Obesity and enhanced diabetes and cardiovascular risk in adult rats due to early postnatal overfeeding. Experimental and Clinical Endocrinology 99 154-158.

Plagemann A, Harder T, Rake A, Waas T, Melchior K, Ziska T, Rohde W \& Dorner G 1999 Observations on the orexigenic hypothalamic neuropeptide Y-system in neonatally overfed weanling rats. Journal of Neuroendocrinology 11 541-546.

Ravelli GP, Stein ZA \& Susser MW 1976 Obesity in young men after famine exposure in utero and early infancy. New England Journal of Medicine 295 349-353.

Reaven G 1988 Banting lecture 1988. Role of insulin resistance in human disease. Diabetes 37 1595-1607.

Saladin R, Devos P, Guerremillo M, Leturque A, Girard J, Staels B \& Auwerx J 1995 Transient increase in obese gene expression after food intake or insulin administration. Nature 377 527-529.

Schwartz MW 2001 Brain pathways controlling food intake and body weight. Experimental Biology of Medicine 226 978-981.
Seufert J, Kieffer TJ, Leech CA, Holz GG, Moritz W, Ricordi C \& Habener JF 1999 Leptin suppression of insulin secretion and gene expression in human pancreatic islets: implications for the development of adipogenic diabetes mellitus. Journal of Clinical and Endocrinological Metabolism 84 670-676.

Shekhawat PS, Garland JS, Shivpuri C, Mick GJ, Sasidharan P, Pelz CJ \& McCormick KL 1998 Neonatal cord blood leptin: its relationship to birth weight, body mass index, maternal diabetes, and steroids. Pediatric Research 43 338-343.

Silverman BL, Rizzo T, Green OC, Cho NH, Winter RJ, Ogata ES, Richards GE \& Metzger BE 1991 Long-term prospective evaluation of offspring of diabetic mothers. Diabetes 40 121-125.

Singhal A, Farooqi IS, O'Rahilly S, Cole TJ, Fewtrell M \& Lucas A 2002 Early nutrition and leptin concentrations in later life. American Journal of Clinical Nutrition 75 993-999.

Singhal A, Wells J, Cole TJ, Fewtrell M \& Lucas A 2003 Programming of lean body mass: a link between birth weight, obesity, and cardiovascular disease? American Journal of Clinical Nutrition 77 $726-730$.

Smith JT \& Waddell BJ 2002 Leptin receptor expression in the rat placenta: changes in Ob-Ra, Ob-Rb, and Ob-Re with gestational age and suppression by glucocorticoids. Biology of Reproduction $671204-1210$.

Smith JT \& Waddell BJ 2003 Leptin distribution and metabolism in the pregnant rat: transplacental leptin passage increases in late gestation but is reduced by excess glucocorticoids. Endocrinology $1443024-3030$.

Sorensen HT, Sabroe S, Rothman KJ, Gillman M, Fischer P \& Sorensen TI 1997 Relation between weight and length at birth and body mass index in young adulthood: cohort study. British Medical Journal 3151137.

Stephens DN 1980 Growth and development of dietary obesity in adulthood of rats which have been undernourished during development. British Journal of Nutrition 44 215-227.

Stevens D, Alexander G \& Bell AW 1990 Effect of prolonged glucose infusion into fetal sheep on body growth, fat deposition and gestation length. Journal of Developmental Physiology 13 277-281.

Stocker C, O'Dowd J, Morton NM, Wargent E, Sennitt M, Hislop D, Glund S, Seckl J, Arch J \& Cawthorne M 2004 Modulation of susceptibility to weight gain and insulin resistance in low birthweight rats by treatment of their mothers with leptin during pregnancy and lactation. International Journal of Obesity Related Metabolic Disorders 28 129-136.

Symonds ME \& Stephenson T 1999 Maternal nutrition and endocrine programming of fetal adipose tissue development. Biochemical Society Transactions 27 97-103.

Tapanainen P, Leinonen E, Ruokonen A \& Knip M 2001 Leptin concentrations are elevated in newborn infants of diabetic mothers. Hormone Research 55 185-190.

Thomas L, Wallace JM, Aitken RP, Mercer JG, Trayhurn P \& Hoggard N 2001 Circulating leptin during ovine pregnancy in relation to maternal nutrition, body composition and pregnancy outcome. Journal of Endocrinology 169 465-476.

Vickers MH, Breier BH, Cutfield WS, Hofman PL \& Gluckman PD 2000 Fetal origins of hyperphagia, obesity, and hypertension and postnatal amplification by hypercaloric nutrition. American Journal of Physiology, Endocrinology and Metabolism 279 E83-E87.

Warnes KE, Morris MJ, Symonds ME, Phillips ID, Clarke IJ, Owens JA \& McMillen IC 1998 Effects of increasing gestation, cortisol and maternal undernutrition on hypothalamic neuropeptide $Y$ expression in the sheep fetus. Journal of Neuroendocrinology $\mathbf{1 0}$ $51-57$.

Williams LM, Adam CL, Mercer JG, Moar KM, Slater D, Hunter L, Findlay PA \& Hoggard N 1999 Leptin receptor and neuropeptide $Y$ gene expression in the sheep brain. Journal of Neuroendocrinology $11165-169$.

Yajnik CS 2003 Nutrition, growth, and body size in relation to insulin resistance and type 2 diabetes. Current Diabetes Reports 3 $108-114$ 
Yuen BSJ, McMillen IC, Symonds ME \& Owens PC 1999 Abundance of leptin mRNA in fetal adipose tissue is related to fetal body weight. Journal of Endocrinology 163 R11-R14.

Yuen BSJ, Owens PC, McFarlane JR, Symonds ME, Edwards LJ, Kauter KG \& McMillen IC 2002 Circulating leptin concentrations are positively related to leptin messenger RNA expression in the adipose tissue of fetal sheep in the pregnant ewe fed at or below maintenance energy requirements during late gestation. Biology of Reproduction 67 911-916.

Yuen BSJ, Owens PC, Muhlhausler BS, Roberts CT, Symonds ME, Keisler DH, McFarlane JR, Kauter KG, Evens Y \& McMillen IC 2003 Leptin alters the structural and functional characteristics of adipose tissue before birth. FASEB Journal 17 1102-1104.
Yuen BSI, Owens PC, Symonds ME, Keisler DH, McFarlane JR, Kauter KG \& McMillen IC 2004 Effects of leptin on fetal plasma adrenocorticotropic hormone and cortisol concentrations and the timing of parturition in the sheep. Biology of Reproduction $\mathbf{7 0}$ $1650-1657$.

Received 22 March 2005

First decision 5 May 2005

Revised manuscript received 9 November 2005

Accepted 17 November 2005 